\title{
RP-HPLC Method Development and Validation for Quantification of Fexofenadine in Pharmaceutical Products
}

\author{
Erten Akbel $^{1 *}$, İbrahim Bulduk ${ }^{2}$ \\ 1*Faculty of Health Sciences, Uşak University, Uşak, Turkey, (ORCID: 0000-0002-6954-3658), erten.akbel@usak.edu.tr \\ ${ }^{2}$ Faculty of Health Sciences, Uşak University, Uşak, Turkey, (ORCID: 0000-0001-6172-7738), ibrahim.bulduk@usak.edu.tr
}

(International Conference on Design, Research and Development (RDCONF) 2021 - 15-18 December 2021)

(DOI:10.31590/ejosat.1044758)

ATIF/REFERENCE: Akbel, E.\&Bulduk, İ. (2021). Development and Validation of RP-HPLC Method for the Quantification of Fexofenadine in Pharmaceutical Preparations. European Journal of Science and Technology, (32), 1048-1053.

\begin{abstract}
Fexofenadine belongs to the antihistamine family of drugs. It is used to treat seasonal allergic rhinitis symptoms. In this study, a rapid, simple and sensitive liquid chromatographic method for the quantitative determination of fexofenadine was optimized and validated. Agilent Extend $\mathrm{C}_{18}$ column was used to perform the separation. The optimum chromatographic separation was achieved by the mobile phase consist of acetonitrile and $20 \mathrm{mM} \mathrm{KH}_{2} \mathrm{PO}_{4}$ solution $\left(\mathrm{pH} \mathrm{7.5)} \mathrm{in} \mathrm{35:65} \mathrm{ratios} \mathrm{respectively.} \mathrm{The} \mathrm{flow} \mathrm{rate} \mathrm{of} 1.2 \mathrm{~mL} \mathrm{~min}^{-1}\right.$ with a standard retention time of $3.5 \mathrm{~min}$ at a wavelength $220 \mathrm{~nm}$ was optimized. The developed method has been validated in terms of their linearity, specificity, precision, accuracy, limits of detection and quantification, and robustness as per I.C.H. guidelines. The developed method has shown excellent linearity, precision, and recovery. There were no spectral or chromatographic interferences from non-medicinal ingredients found. Within a concentration range of $10-60 \mathrm{~g} \mathrm{~mL}^{-1}$, the correlation coefficient was greater than 0.999. Low relative standard deviation values were obtained in the results of intra-day and inter-day precision tests. The method's accuracy ranged from 99.45 to $100.52 \%$. The present analytical method can be used to quantify fexofenadine in pharmaceutical preparations.
\end{abstract}

Keywords: Fexofenadine, analysis, method, validation

\section{Farmasötik Preparatlarda Feksofenadin Kantifikasyonu için RP- HPLC Yönteminin Geliştirilmesi ve Validasyonu}

Öz

Feksofenadin, antihistamin ilaç ailesindendir. Mevsimsel alerjik rinit semptomlarını tedavi etmek için kullanılır. Bu çalışmada, feksofenadinin kantitatif tayini için basit, hızlı ve hassas yüksek performanslı sıvı kromatografik yöntem gelitirilmiş ve valide edilmiştir. Ayırma işlemini gerçekleştirmek için Agilent Extend $\mathrm{C}_{18}$ kolon kullanıldı. Optimum kromatografik ayırma, hacimsel olarak sırasıyla 35:65 oranlarında asetonitril ve $20 \mathrm{mM} \mathrm{KH}_{2} \mathrm{P}_{4}$ çözeltisinden (pH 7.5) oluşan mobil faz ile sağlandı. $220 \mathrm{~nm}$ dalga boyunda 3.5 dakikalık standart alıkonma süresi ile $1.2 \mathrm{~mL}$ dak $^{-1}$ akış hızı optimize edildi. Geliştirilen yöntemin, lineerliğgi, özgünlüğü, kesinliği, doğruluğu, saptama ve kantifikasyon limitleri ve sağlamlığı I.C.H. yönergelerine göre doğrulanmıştır. Geliştirilen yöntem iyi bir doğrusallık, kesinlik ve geri kazanım göstermiştir. Tıbbi olmayan bileşenlerden hiçbir kromatografik etkileşim gözlenmedi. Korelasyon katsayısı, 10-60 $\mu \mathrm{g} \mathrm{mL} \mathrm{m}^{-1}$ konsantrasyon aralığında 0,999'dan büyüktü. Gün içi ve günler arası kesinlik testleri sonuçlarında düşük bağıl standart sapma değerleri elde edilmiştir. Yöntemin doğruluğu \% 99.45-100.52 aralığındaydı. Mevcut analitik yöntem, farmasötik preparasyonlarda feksofenadin miktarının belirlenmesi için kullanılabilir.

Anahtar kelimeler: Fexofenadine, analiz, metod, validasyon

Corresponding Author: erten.akbel@usak.edu.tr 


\subsection{Equipments}

\section{Introduction}

Fexofenadine belongs to the antihistamine family of drugs. It is used to treat seasonal allergic rhinitis symptoms such as runny nose and sneezing. It works by preventing the release of histamine, a chemical in the body that causes allergic reactions [1]. It has non-sedative properties and is a histamine $\mathrm{H} 1$ receptor antagonist. This is due to its capacity to exist in the zwitterionic state, which does not penetrate the blood-brain barrier and so does not produce sedation [2,3]. It is a second generation antihistamine with a wide safety margin that can be used to supplement existing allergy treatments $[4,5]$.

It is an anti-inflammatory medication. It also doesn't demonstrate terfenadine's cardiotoxic adverse effects [2,3]. Fexofenadine is quickly absorbed and has a lengthy duration of action, making it suited for once-daily treatment. As a result, it is an ideal antihistamine capable of improving the quality of life of patients suffering from allergic disease. It fully meets the desired basic properties $[4,6]$. The chemical properties of fexofenadine has been presented in Table 1[7].

A review of the literature found several reports on the liquid chromatographic determination of fexofenadine in biological fluids. Among these are those that use LC-MS/MS [8, 9], ultraviolet detection [10], and fluorescence detection. Few methods for measuring FEX in pharmaceutical dosage forms have been reported, including spectrophotometric methods [11], LC methods with ultraviolet detection [12-14], and capillary electrophoresis $[15,16]$. The fexofenadine monograph is officially available in both the United States Pharmacopoeia and the British Pharmacopoeia describing the high-pressure liquid chromatography (HPLC) technique for the quantification of fexofenadine in bulk powder $[17,18]$.

However, these methods had limitations such as sample preparation, gradient elution, run time. These procedures also need the use of expensive equipment, specialized reagents, and significant volumes of organic solvents. The goal of this research is to create simple, quick, low-cost, and well-validated analytical methods for quantifying fexofenadine in pharmaceutical formulations using LC chromatographic technique. The developed analytical method was validated in accordance with the procedures outlined in ICH guidelines Q2(R1) for analytical method validation $[19,20]$. Furthermore, the applicability and dependability of this method was evaluated by focusing on routine quality control analyses.

\section{Material and Method \\ 2.1. Equipments}

The analytical method was developed on an Agilent 1260 HPLC system. HPLC system included Chemstation software, a UV-Vis detector, an autosampler sampler, a quaternary pump, a thermostated column a degasser compartment. The detection wavelength of the analyte was determined in the Shimadzu UV1800 spectrophotometer device. The spectrophotometer device was dual-beam path and analyzes were made with UV-Probe software using $1.0 \mathrm{~cm}$ quartz cell. The ultrapure water used in the analyzes was produced using a Milli-Q water purification system (Millipore).
Fexofenadine $\mathrm{HCl}$ Pharmaceutical Secondary Standard (Certified Reference Material) methanol $(\geq 99.9 \%)$, and acetonitrile $(\geq 99.9 \%)$ was purchased from Sigma-Aldrich Chemie GmbH. Allegro ${ }^{\circledR}$ film tablet $(120 \mathrm{mg})$ was bought from the local pharmacy. Ultrapure water was produced using a Merck Millipore water purification system (Bedford, MA, USA).

\subsection{Standard solutions}

By dissolving the appropriate amount of fexofenadine $\mathrm{HCl}$ in ultra-pure water, a stock standard solution $\left(500 \mathrm{~g} \mathrm{~mL}^{-1}\right)$ was prepared. To obtain working standard solutions with concentrations ranging from 10 to $60 \mathrm{~g} \mathrm{~mL}^{-1}(\mathrm{n}=6)$, serial dilutions of the stock standard solution were prepared using ultrapure water.

\subsection{Determination of the detection wavelength}

Using ultra-pure water, the spectrophotometer was calibrated to zero. 0.45 micron injector-tip filters were used to filter standard solutions. The spectrophotometer instrument was used to scan the standard solutions in the wavelength range of 200-800 nm, and the wavelength at which fexofenadine absorbed the most was found.

\subsection{Calibration curves}

Standard and sample solutions were filtered through 0.45 micron syringe filters and injected into the HPLC system at a fixed injection volume $(20 \mu \mathrm{L})$. A calibration graph was constructed by plotting the concentration versus area of the peak. Slope, intercept and correlation coefficient were calculated from this calibration curve by performing regression analysis.

\subsection{Assay of fexofenadine in tablets}

The ten tablets were each individually weighed precisely and ground into a fine powder in a mortar. Ground tablet powder equivalent to $50 \mathrm{mg}$ of fexofenadine was precisely weighed and transferred to a $100 \mathrm{~mL}$ volumetric flask. $50 \mathrm{~mL}$ of ultrapure water was added. The contents were sonicated for 5 minutes to thoroughly dissolve the drugs and then diluted to the mark with ultrapure water. A $1.00 \mathrm{~mL}$ aliquot was taken from the prepared solution, transferred to a $10 \mathrm{~mL}$ volumetric flask and diluted with water up to the mark $(50 \mu \mathrm{g} \mathrm{mL}-1)$. $20 \mu \mathrm{L}$ of sample solution was injected three times into the HPLC system. Sample solutions were analyzed using the proposed method, peak areas were determined for fexofenadine, and active ingredient contents in the tablet were calculated.

\subsection{Analysis method conditions}

Chromatographic analyzes were carried out using Agilent brand 1260 model liquid chromatography device with UV-Vis detector. The mobile phase was determined as a $20 \mathrm{mM} \mathrm{KH}_{2} \mathrm{PO}_{4}$ solution at a flow rate of $1.2 \mathrm{~mL} \mathrm{~min}^{-1}$. The mobile phase was filtered using a $0.45 \mathrm{~mm}$ membrane filter before use and degassed in a sonicator for $5 \mathrm{~min}$. Chromatographic separation was performed on an ODS $(4.6 \mathrm{~mm} \times 250 \mathrm{~mm}, 5 \mu \mathrm{m}$ particle size) column held constant at $25{ }^{\circ} \mathrm{C}$. Detection of fexofenadine was done with a UV detector at $220 \mathrm{~nm}$. The operating time under these conditions was determined to be 10 minutes. 
Table 1. Chemical properties of fexofenadine

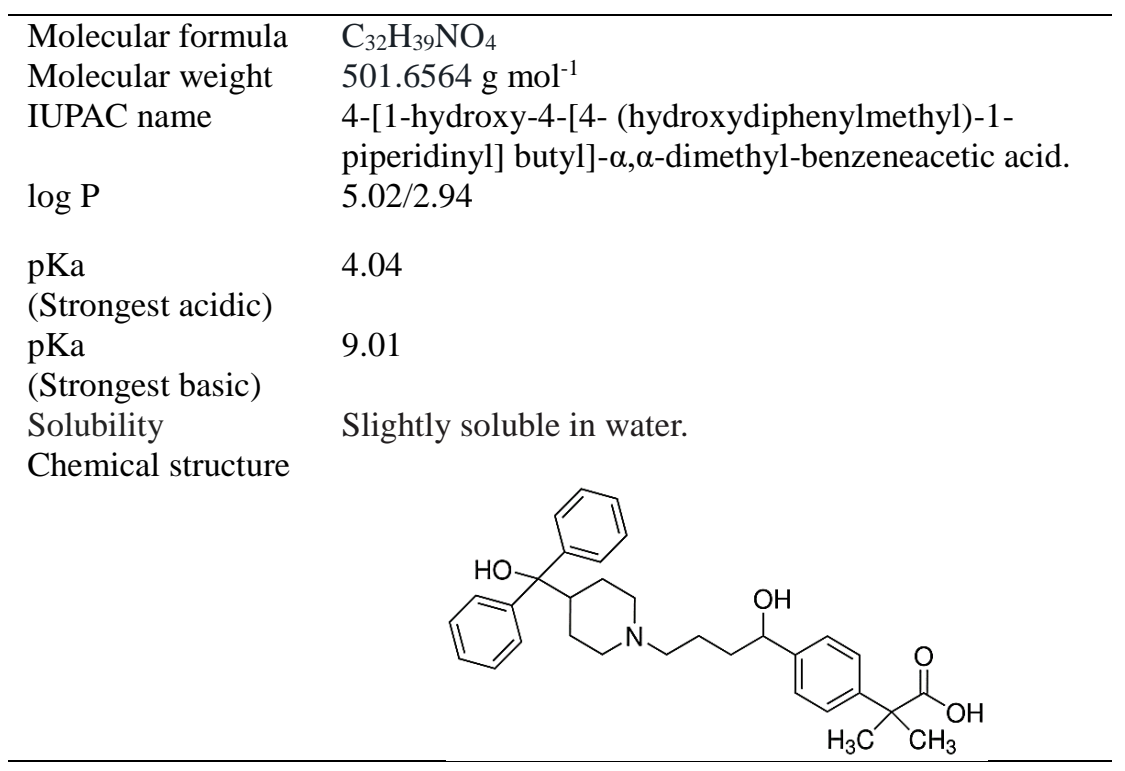

\subsection{Validation of Analytical Method}

Analytical method was validated in accordance with the procedures outlined in ICH guidelines Q2(R1) for analytical method validation [19,20]. Accuracy, linearity, system compatibility tests, sensitivity, precision, robustness, originality, and stability studies were examined as validation parameters. For the validation of the chromatographic method, fexofenadine standard solutions were prepared in triplicate with ultrapure water in the concentration range of 10-60 $\mu \mathrm{g}$ $\mathrm{mL}^{-1}$. Then, Each standard solution $(20 \mu \mathrm{l})$ was injected into the chromatographic system, and the retention time and fexofenadine peak area and were measured and recorded. A calibration curve was created by plotting the plot of the peak area versus the concentration of standard fexofenadine solutions. Linearity was determined using regression analysis. Intercept, slope and correlation coefficient values were determined by regression analysis. The accuracy of the analytical method was determined using the standard addition method to the sample solution. Three different levels of standard $(120 \%, 100 \%$, and $80 \%$ of concentration) were added to the sample solution analyzed earlier. The samples were analyzed using the developed analysis method. Recovery\% and RSD\% values were calculated for each concentration. The reproducibility (within-day) and intermediate precision (between-days) of the analytical method were used to evaluate its precision. In intraday precision studies, fexofenadine standard solution at three different concentrations (40, 50 and $60 \mathrm{~g} \mathrm{~mL}-1)$ was injected into the system six times in the same day, and the responses were determined. In between-day precision studies, standard solutions were injected into the system three times in three consecutive days and the responses were determined. Detection (LOD) and quantification (LOQ) limit were used to evaluate the sensitivity of the chromatographic method. LOD and LOQ values were calculated from the regression analysis using the following equations.

$$
\mathrm{LOD}=3.3 \mathrm{x} \sigma / \mathrm{S} \text { and } \mathrm{LOQ}=10 \mathrm{x} \sigma / \mathrm{S},
$$

where, $\sigma$ : standard deviation of $y$ intercept of calibration curve and $\mathrm{S}=$ slope of the calibration curve.

The specificity of the fexofenadine peak was determined from chromatograms at three regions (start, peak, and end of the peak).

The robustness of the analytical method was evaluated by looking at how small but deliberate changes in method parameters affected the analysis results. For this, the same standard solution was analyzed under different conditions such as changes in detection wavelengths $(2 \mathrm{~nm})$, and mobile phase flow rate $\left(0.1 \mathrm{ml} \mathrm{min}^{-1}\right)$. System suitability parameters were determined.

For system compatibility tests, standard fexofenadine solution at a concentration of $30 \mathrm{~g} \mathrm{~mL}^{-1}$ was injected into the chromatographic system six times. Fexofenadine peak areas, tailing factors, capacity factors, theoretical plate numbers and asymmetric factors were recorded. For stability studies; Fexofenadine standard solution was stored under laboratory bench conditions for up to two days and in the refrigerator (4 $\left.{ }^{\circ} \mathrm{C}\right)$ for up to five days. Afterwards, These solutions were analyzed once every eight hours with the developed chromatographic method.

\section{Results and Discussion}

A new analytical method was described for the quantification of fexofenadine in pharmaceutical products.

\subsection{Determination of $\lambda_{\max }$}

Standard solutions were scanned in a spectrophotometer device in the wavelength range of $200-800 \mathrm{~nm}$. The $\lambda_{\max }$ value for all standard solutions was determined as $220 \mathrm{~nm}$. The overlap spectrum of standard solutions is presented in Figure 1. 


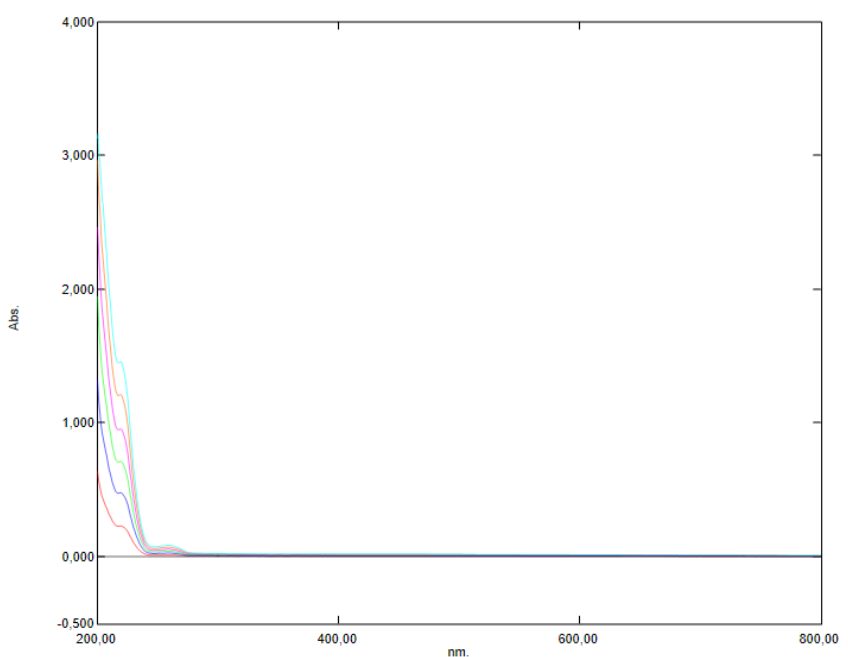

Figure 1. The overlay spectrum (standard solutions)

\subsection{HPLC Method}

Chromatographic conditions were optimized after meticulous work. The chemical composition, $\mathrm{pH}$, flow rate and $\mathrm{pH}$ of the mobile phase were determined depending on the analysis time, peak shape (symmetry and tailing factor), cost of solvents, and baseline shift. Several mobile phases were tried to achieve a perfect separation. In the end, $20 \mathrm{mM}$ $\mathrm{KH}_{2} \mathrm{PO}_{4}(\mathrm{pH} 7.50)$ solution in water and acetonitrile was decided to be the best mobile phase for short working time, symmetrical peak and acceptable $\mathrm{K}$ value.

Overlapping chromatograms of standard solutions are given in Figure 2. The linearity graph of the standard solutions is presented in Figure 3. The retention time of Fexofenadine was determined as 3.50 minutes under the specified conditions. The oproposed analytical method was validated in terms of system suitability, accuracy, linearity, specificity, sensitivity (LOD and LOQ), precision, and robustness. Fexofenadine was found to have a purity of 0.9999 at its peak, and the proposed approach was found to be unique.

By performing linear regression analysis, it was determined that the analyte concentration and peak area had a perfect correlation. The calibration curve for the standards was linear in the concentration range of 10 to $60 \mu \mathrm{g} \mathrm{mL}^{-1}$ and the correlation coefficient was determined as $0.9999 \pm 0.0005$, the linear regression equation was determined as $\mathrm{Y}=23.685 \mathrm{X}$ 14.987. The detection and quantification limits were determined as $1.50 \mu \mathrm{g} \mathrm{mL}-1$ and $4.50 \mu \mathrm{g} \mathrm{mL}-1$, respectively, which indicates the sensitivity of the method.

The findings and statistical assessments in Table 2 demonstrate the method's excellent accuracy and precision. Recovery experiments revealed high accuracy and minimal relative standard deviations (R.S.D. \%). Because the R.S.D. percent values for repeatability and intermediate precision studies were 2 as indicated by the ICH criteria, the devised HPLC technique was judged to be exact. R.S.D.\% of repeatability (intra-day) and intermediate precision (inter-day) ranged from 0.1240 to 0.1745 and 0.2130 to 0.2855 respectively. The validation and regression parameters of fexofenadine using propoed method was shown in Table 2.
Table 2. Validation parameters $(n=6)$

\begin{tabular}{|c|c|c|}
\hline \multicolumn{2}{|c|}{ Parameter } & Value \\
\hline \multicolumn{2}{|c|}{ Range of concentration $\left(\mu \mathrm{g} \mathrm{mL} \mathrm{m}^{-1}\right)$} & $10-60$ \\
\hline \multicolumn{2}{|c|}{$\begin{array}{l}\text { Detection limit/quantificaion limit } \\
\left(\mu \mathrm{g} \mathrm{mL}^{-1}\right)\end{array}$} & $1.50 / 4.50$ \\
\hline \multicolumn{2}{|c|}{ Slope } & $23.685 \pm 0.008$ \\
\hline \multicolumn{2}{|c|}{ Standard error of slope } & 3.624 \\
\hline \multicolumn{2}{|c|}{ Intercept } & $-14.987 \pm 0.005$ \\
\hline \multicolumn{2}{|c|}{ Standard error of intercept } & 4.385 \\
\hline \multicolumn{2}{|c|}{ Correlation coefficient } & $0.9999 \pm 0.0007$ \\
\hline \multicolumn{2}{|c|}{ Standard deviation (residuals) } & 0.41 \\
\hline \multicolumn{2}{|c|}{ Recovery (\%) } & $100.10 \pm 0.88$ \\
\hline Precision & Intraday & $0.1240-0.1745$ \\
\hline (R.S.D.\%) & Interday & $0.2130-0.2855$ \\
\hline
\end{tabular}

Intentional minor modifications to the method conditions did not have a high event effect on peak symmetry and did not significantly alter the fexofenadine retention time. R.S.D.\% values for each parameter of the method were calculated and it was seen that all of them were less than 2 . The amount of fexofenadine in the reference material analyzed by the developed method was determined as $100.10 \pm 0.88$. System suitability tests have shown that the chromatographic method developed for fexofenadine analysis in routine laboratory studies is suitable. The capacity factor for the fexofenadine peak was determined as 10.20 with Chemstation software. The tailing factor of the fexofenadine peak was also determined by the firmware to be 1.158 showing good peak symmetry. The theoretical plate number was determined as 4975, showing high column efficiency. System suitability tests are given in Table 3, revealing that the analytical method developed meets these requirements. Data obtained from studies to determine the stability of standard solutions have shown that standard solutions are stable for 48 hours at room conditions.

Table 3. System suitability test results

\begin{tabular}{lc}
\hline Parameters of system suitability tests & Value \\
\hline Retention time of fexofenadine & 3.95 \\
Peak purity index for & 0.9985 \\
Peak asymetry & 0.8480 \\
Tailing factor for fexofenadine & 1.1584 \\
Capacity factor of fexofenadine peak & 10.20 \\
Theoritical plates number & 4975 \\
\hline
\end{tabular}

\subsection{Application of analytical method to pharmaceutical products}

Developed analytical method was applied to pharmaceutical products. Analysis results for tablet containing fexofenadine are given in Table 4. It has been observed that the analysis results are very close to the amounts stated on the labels of pharmaceutical products. 
Table 4. Application results

\begin{tabular}{lccc}
\hline $\begin{array}{l}\text { Commercial } \\
\text { Formulation }\end{array}$ & $\begin{array}{c}\text { Label claim } \\
(\mathbf{m g} / \text { tablet })\end{array}$ & $\begin{array}{c}\text { Found } \\
\text { Fexofenadine } \\
\text { (mg/tablet) }\end{array}$ & $\begin{array}{c}\text { Assay \% } \\
\pm \text { S.D. }\end{array}$ \\
\hline Allegro ${ }^{\circledR}$ & 120 & 119.85 & $99.88 \pm$ \\
film tablet & & & 0.88 \\
$(120 \mathrm{mg})$ & & & \\
\hline
\end{tabular}

\subsection{Stability of standard solutions}

Over the course of a 48-hour period, stability of the reference standard solutions was examined. For this purpose, standard solutions were injected into the HPLC system with 8hour periods and the retention time and peak area were recorded. Table 5 shows the results of the stability study. The R.S.D.\% was determined as 0.060 for peak area and $0.217 \%$ for retention time. No significant changes in the concentration of the active pharmaceutical ingredient in the standard solution were observed.

Table 5. Standard solution stability

\begin{tabular}{ccccccccc}
$\begin{array}{c}\text { Time, } \\
\text { hours }\end{array}$ & $\begin{array}{c}\text { Peak } \\
\text { area }\end{array}$ & Mean & S.D. & $\begin{array}{c}\text { R.S.D. } \\
\%\end{array}$ & $\begin{array}{c}\text { Retention time } \\
(\mathbf{m i n})\end{array}$ & $\begin{array}{c}\text { Mean } \\
\pm \text { S.D. }\end{array}$ & S.D. & $\begin{array}{c}\text { R.S.D. } \\
\%\end{array}$ \\
\hline \multirow{2}{*}{0} & 1175.6 & & & & 3.489 & & & \\
& 1174.8 & 1175.5 & 0.7 & 0.060 & 3.491 & 3.486 & 0.008 & 0.217 \\
& 1176.2 & & & & 3.477 & & & \\
\multirow{2}{*}{24} & 1175.1 & & & & 3.485 & & & \\
& 1175.6 & 1175.0 & 0.7 & 0.056 & 3.491 & 3.486 & 0.004 & 0.119 \\
& 1174.3 & & & & 3.483 & & & \\
& 1174.6 & & & & 3.482 & & & \\
& 1175.3 & 1175.2 & 0.6 & 0.051 & 3.495 & 3.488 & 0.007 & 0.188 \\
& 1175.8 & & & & 3.487 & & & \\
\hline
\end{tabular}

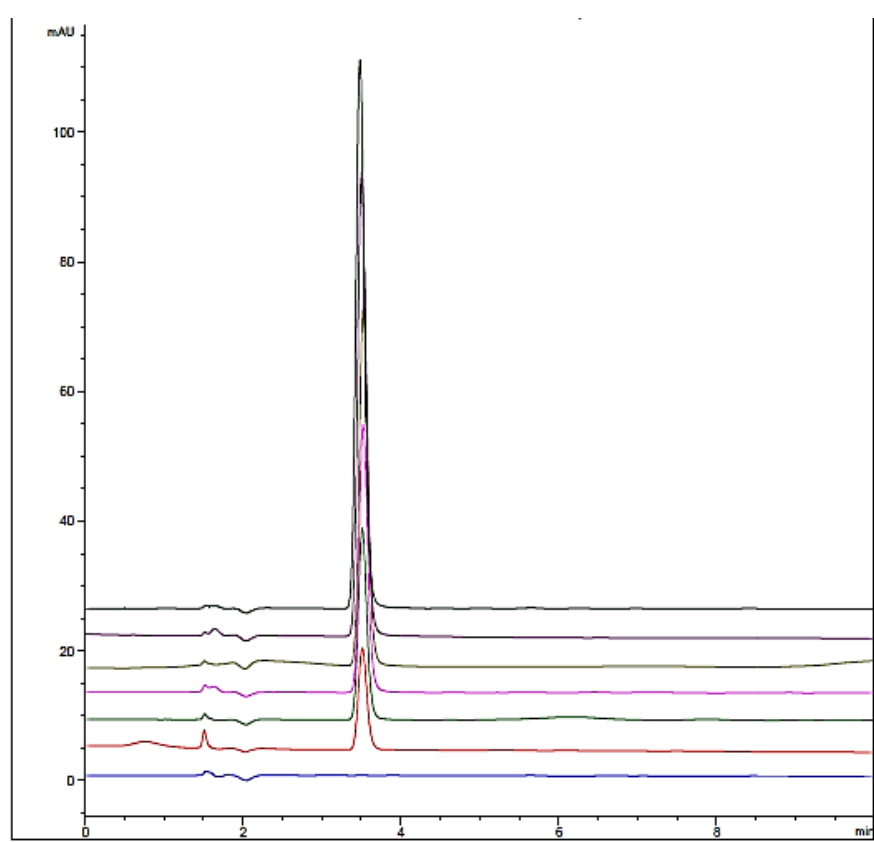

Figure 2. Overlay chromatograms (standard solutions)

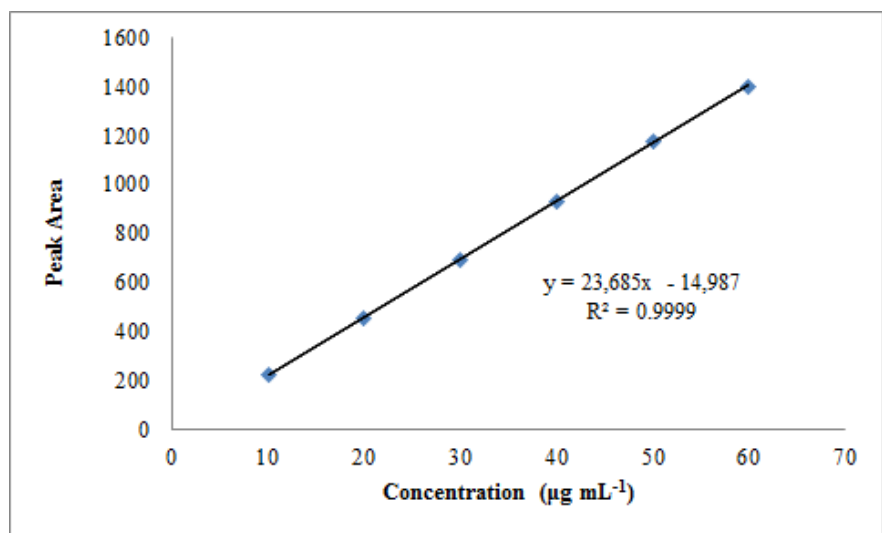

Figure 3. Linearity graph (standard solutions)

To assess the quantity of fexofenadine in pharmaceutical formulations, chromatographic method was established in this study. The chromatographic conditions of the developed analytical method were optimized and validated. Various analytical methods have been previously reported for the quantification of fexofenadine in pharmaceutical formulations. Some of these methods are quite complex. These methods use expensive equipment, large amounts of organic solvents and special reagents. Analysis times are long. It requires a complex sample preparation process. 


\section{Conclusions and Recommendations}

The results show that developed chromatographic method is sufficient methods for the quantification of fexofenadine in parmaceutical formulations. No interfering peaks were observed during the retention time of fexofenadine in the chromatographic method. Because these analytical method is rapid, simple, precise, specific and accurate, it can be applied successfully for routine quality control analysis of fexofenadine in pharmaceutical preparations.

\section{References}

1. O'Neil MJ: The Merck index: an encyclopedia of chemicals, drugs, and biological. 13 edition. Merck \& Co., Inc., Whitehouse Station, NJ; 2001.

2. Simpson K, Jarvis B: Fexofenadine: a review of its use in the management of seasonal allergic rhinitis and chronic idiopathic urticaria. Drugs 2000, 59:301-321.

3. Meeves SG, Appajosyula S: Efficacy and safety profile of fexofenadine HCL: A unique therapeutic option in H1receptor antagonist treatment. J Allergy Clin Immunol 2003, 112:S69-S77.

4. Rita Breier A, Nudelman NS, Steppe M, Schapoval EES: Isolation and structure elucidation of photodegradation products of fexofenadine. J Pharm Biomed Anal 2008, 46:250-257.

5. Estelle F, Simons R: Antihistamines. In Allergy.. 2 edition. Edited by: Kaplan AP. Saunders WB Company, Philadelphia; 2002:834-863.

6. Howarth PH: The choice of an H1-antihistamine for the 21st century. Clin Exp Allergy 2002, 2:18-25.

7. https://www.drugs.com/mtm/fexofenadine. html

8. Guo D, Zou J, Zhu Y, Lou S, Fan H, Qin Q: Measurement of fexofenadine concentration in micro-sample human plasma by a rapid and sensitive LC-MS/MS employing protein precipitation: application to a clinical pharmacokinetic study. Biomed Chromatogr 2010, 24:335-341.

9. Arayne MS, Sultana N, Shehnaz H, Haider A: RP-HPLC method for the quantitative determination of fexofenadine hydrochloride in coated tablets and human serum. Med Chem Res 2011, 20:55-61.
10. Konieczna L, Plenis A, Oledzka I, Kowalski P, Baczek T: Rapid RP-LC method with fluorescence detection for analysis of fexofenadine in human plasma. Chromatographia 2010, 71:1081-1086.

11. Gazy AA, Mahgoub H, El-Yazbi FA, El-Sayed MA, Youssef RM: Determination of some histamine H1-receptor antagonists in dosage forms. J Pharm Biomed Anal 2002, 30:859-867.

12.Ulavapalli KR, Sriramulu J, Mallu UR, Bobbarala V: Simultaneous determination of psuedoephedrine, fexofenadine and loratadine in pharmaceutical products using high resolution RP-HPLC method. J Pharm Res 2011, 4:12191221.

13. Breier, A. R., Paim, C. S., Menegola, J., Steppe, M., Schapoval, E. E., \& Schapoval, E. E. (2004). Development and validation of a liquid chromatographic method for fexofenadine hydrochloride in capsules. Journal of AOAC International, 87(5), 1093-1097.

14.Karakuş S, Küçükgüzel I, Küçükgüzel SG: Development and validation of a rapid RP-HPLC method for the determination of cetirizine or fexofenadine with pseudoephedrine in binary pharmaceutical dosage forms. J Pharm Biomed Anal 2008, 46:295-302.

15. Breier AR, Garcia SS, Jablonski A, Steppe M, Schapoval EES: Capillary electrophoresis method for fexofenadine hydrochloride in capsules. J AOAC Int 2005, 88:1059-1063.

16.Mikus $\mathrm{P}$, Valásková $\mathrm{I}$, Havránek $\mathrm{E}$ : Determination of fexofenadine in tablets by capillary electrophoresis in free solution and in solution with cyclodextrins as analyte carriers. Drug Dev Ind Pharm 2005, 31:795-801.

17.The United States Pharmacopeia, 31th edition. The Official monograph, The United States Pharmacopeial Convention, Rockville, MD, (2011); pp. 1186-1187.

18. The British Pharmacopoeia, Her Majesty's Stationery Office, London, (2010); pp. $46-48$.

19. ICH. (2005). Q2 (R1), harmonized tripartite guideline, validation of analytical procedures: text and methodology, In Proceedings of the International Conference on Harmonization of Technical Requirements for Registration of Pharmaceuticals for Human Use.

20. Center for Drug Evaluation and Research (CDER). (1994). Reviewer Guidance: Validation of Chromatographic Methods. 